\title{
Comparison of dyad training method with cooperative and competitive approach in the learning of Basketball Free Throw
}

Parvin Poor, S. (Ph.D). Kharazmi University of Tehran, Tehran, Iran

Roohi, M. (Ph.D). Nasibeh Teacher Training College, Tehran, Iran

Raad, F. (M.A). Nasibeh Teacher Training College, Tehran, Iran

\begin{abstract}
This study aimed to Comparison of dyad training method with cooperative and competitive approach in the learning of Basketball Free Throw. The study sample included 24 girl's students aged 13-15 years old who had no experience in free throw. Based on pretest scores, the participants were assigned to either the cooperative dyad training group or the competitive dyad training group. In the competitive dyad training condition, individuals in each dyad had to compete with each other to secure the highest free throw score. At the end of each training session the winner was rewarded. In contrast, in the cooperative dyad training condition, the dyads that attained the score of 75 or more in each training session were rewarded. After the 10th training session, the acquisition of free throw skill was assessed. A week later, the retention and the transfer of free throw skill were assessed. The results indicated that, with regard to the acquisition of free throw skill, in both conditions the participants had made statistically significant progress. In terms of the acquisition and the retention of the target skill, no statistically significant differences were observed between cooperative and competitive training groups. However, with regard to transfer test, the cooperative training group outperformed the competitive training group. Therefore, in comparison to competitive dyad training, cooperative dyad training is more conducive to the acquisition and the retention of free throw skill.
\end{abstract}

Keywords: Observational Learning, Cooperative Learning, Dyad Training, Basketball Free Throw 


\title{
مقايسه روش تمرينى دونفره با رويكرد مشار كتى و رقابتى در يادكيرى مهارت يرتاب آزاد بسكتبال
}

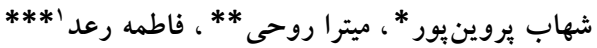

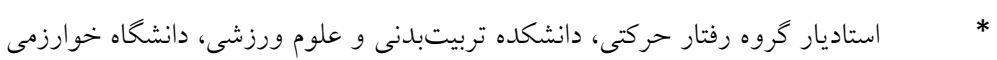 \\ مدير كروه تربيت بدنى ثرديس نسيبه تهران \\ كارشناس ارشد رفتار حركتى
}

هدف از يزوهش حاضـر، مقايسـه روش تمرينى دونفره با رويكرد مشـاركتى و رقابتى در يادگيرى مهارت برتاب آزاد

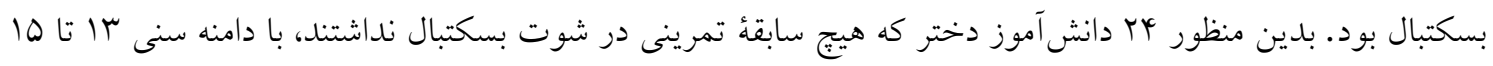

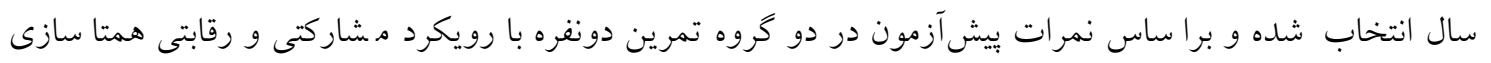

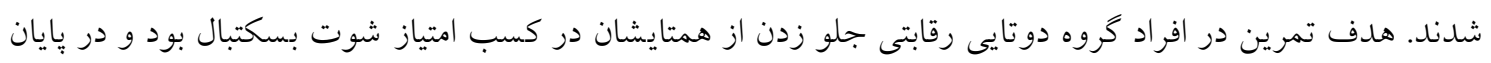

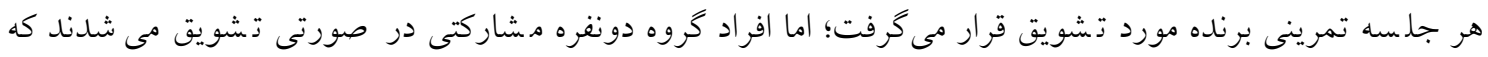

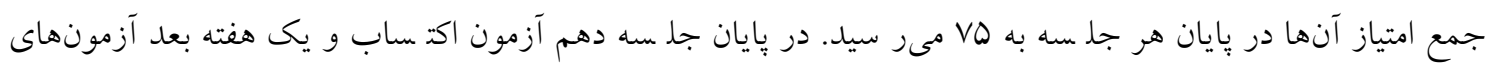

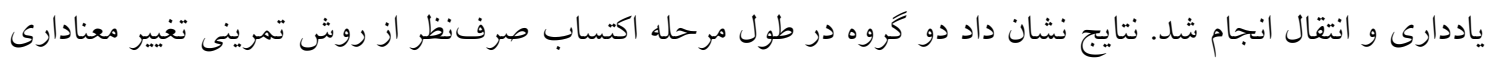

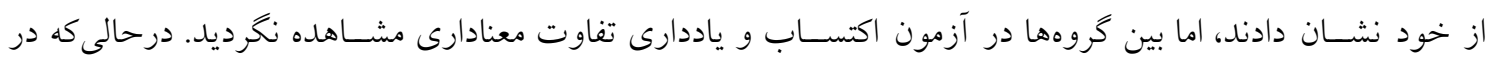

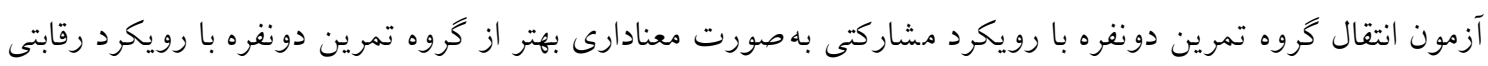

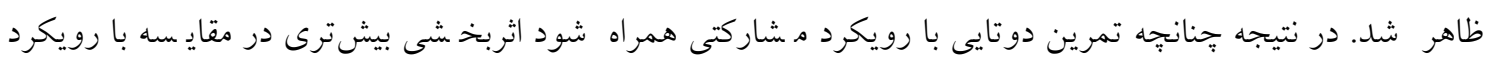

$$
\text { رقابتى به ارمغان خو اهد آورد. }
$$

وازههاى كليدى: يادگيرى مشاهدهاى، يادكيرى مشاركتى، روش تمرين دوتايى، برتباب آزاد بسكتبال 
يبشرفت علم و كسترش دامنه علوم مختلف، ضرورت كسب معلومات بيشتر و بادوامتر در زمان كو تاهتر را اجتنابنايذير مى سازد.

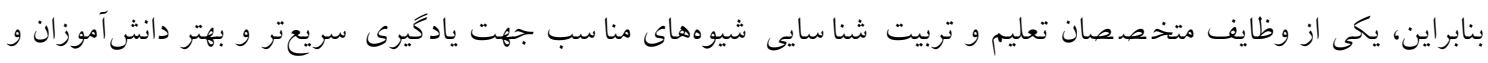

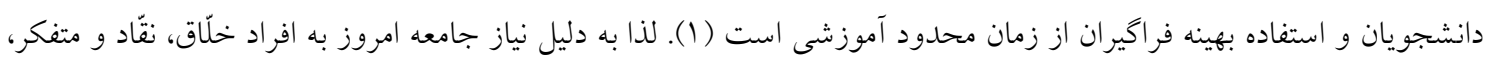

ضرورت تغيير روشهاى تدريس بيشازييش احساس مىشود (Y).

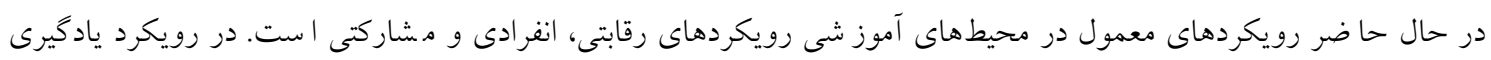

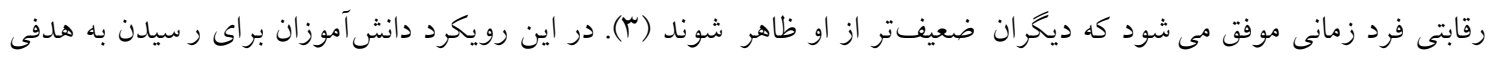

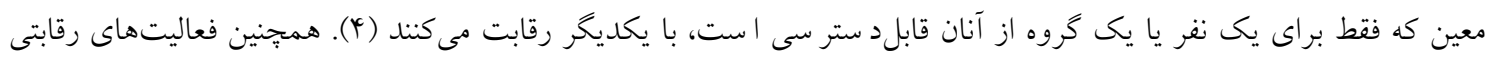

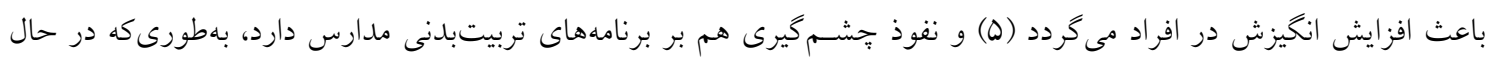

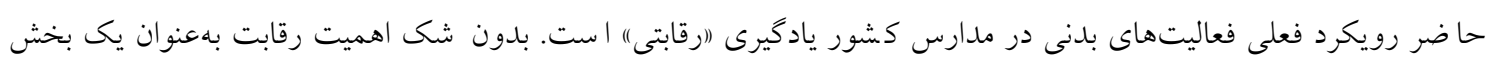

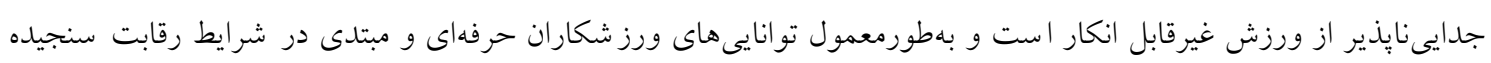
مىشود (9).

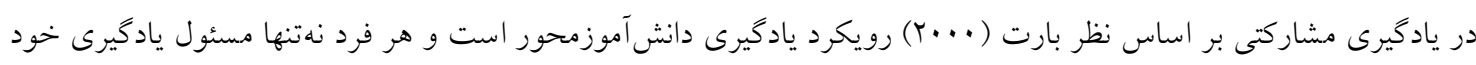

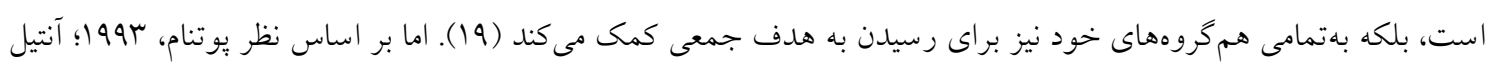

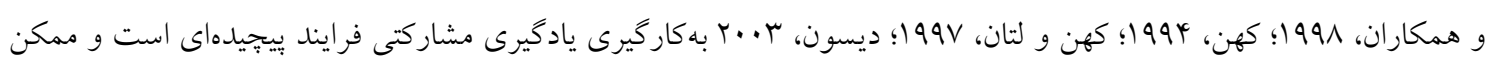

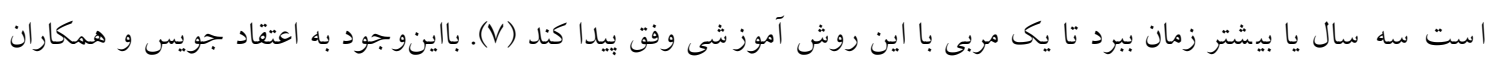

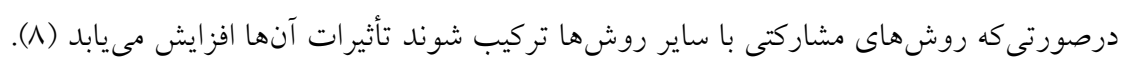

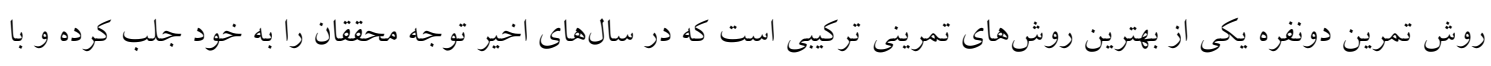

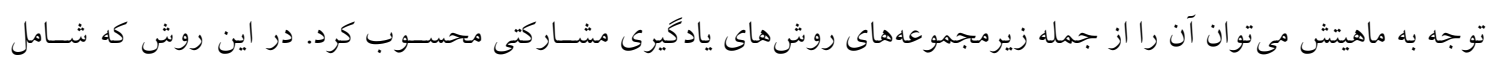

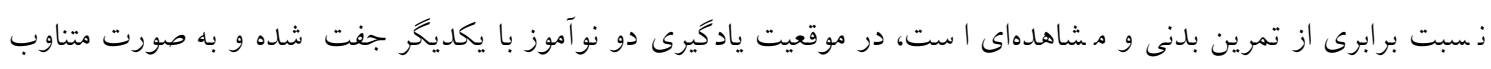

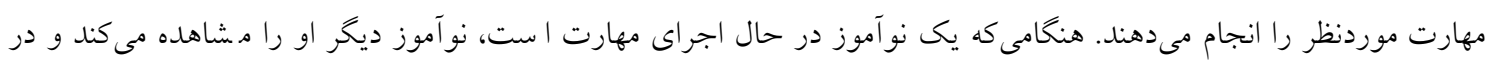

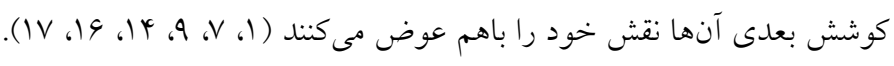

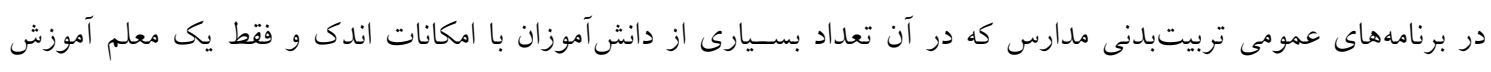

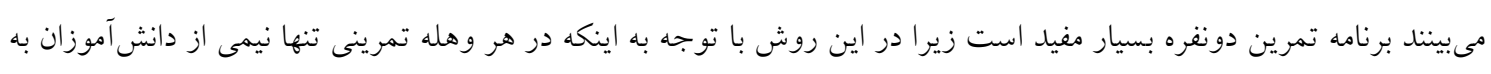

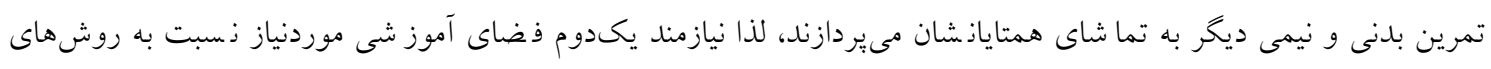

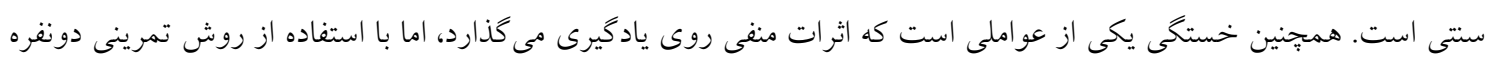

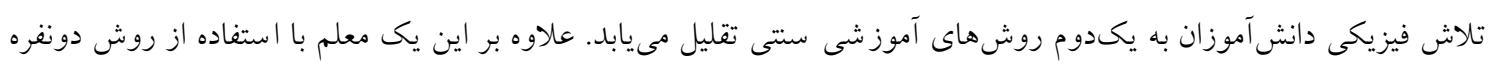

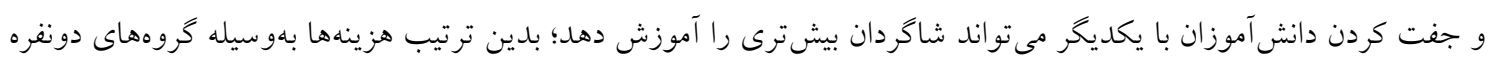

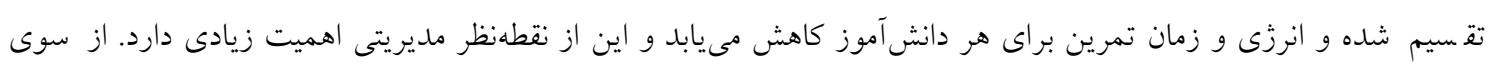

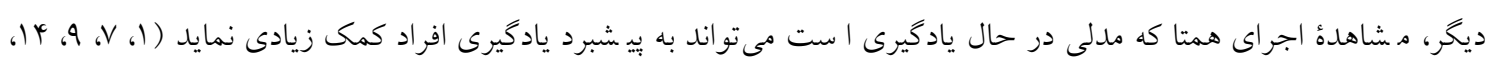

(IV 19

اكثر مطالعات انجامشده درزمينة مقايسه تأثير رويكردهاى يادكيرى مشاركتى و رقابتى به نتايج متفاوتى دست يافتهاند. براساس نظر

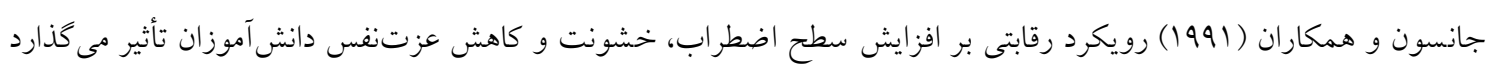

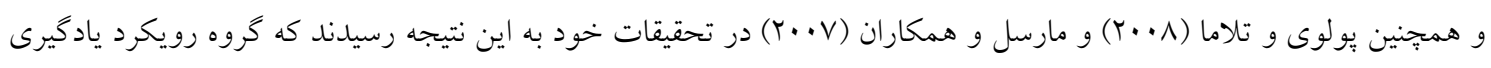

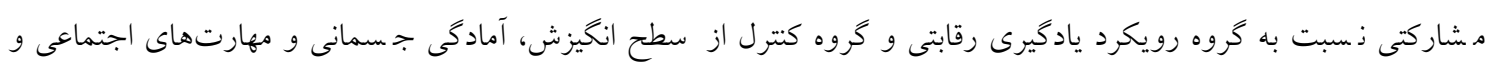

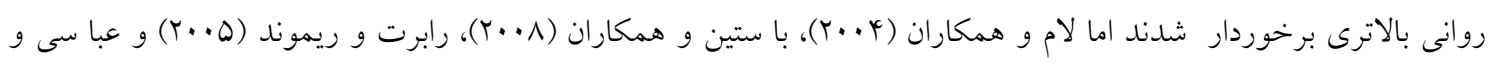

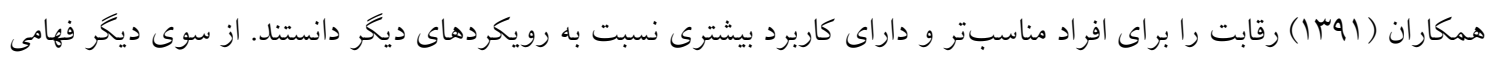




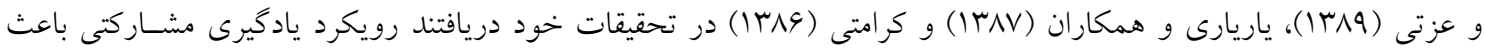
رشد مؤلفهاى مهارتهاى اجتماعى و عزتنفس در دانش آموزان مىشود.

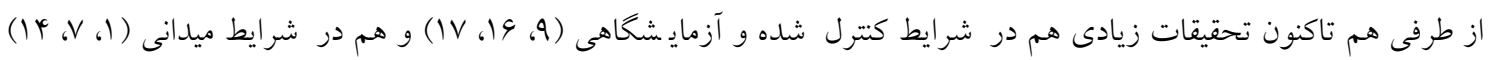

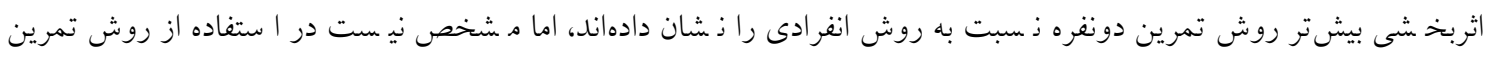

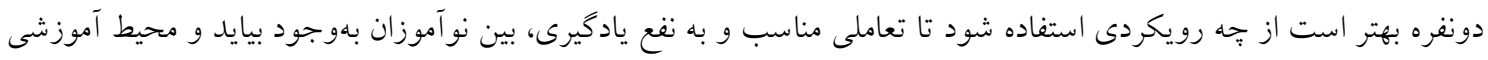
به شرايط ايده آل نزديكتر شود. بنابر اين، با توجه به كمبود تحقيقات در كشــف مؤثرترين روش تمرين دونفره و نيز نبود تحقيقى كه تأثير يادكيرى مشــاركتى و رقابتى را با اسـتفاده از روش تمرين دونفره مورد بررسسى قرار دهد، لذا تحقيق حاضـر قصسـ دارد بررسسى كند كه روش تمرين

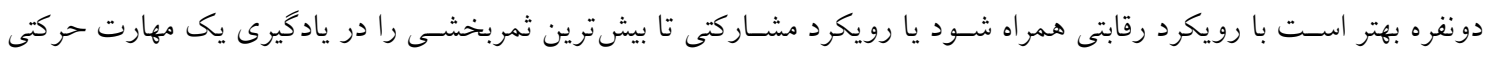

\section{روششناسى \\ آزمودنىها}

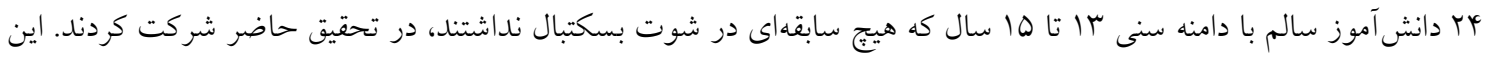

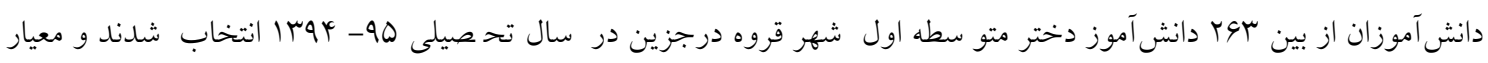

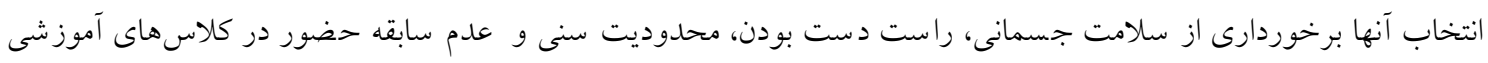
بسكتبال بود. شركت كنندگان با رضايت خود و والدين در اين تحقيق شركت كردند.

\section{ابزار اندازهيرى}

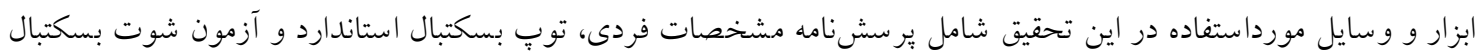

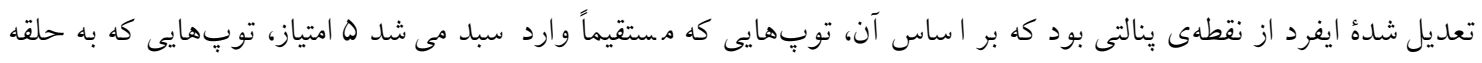

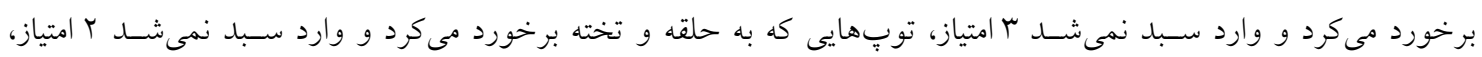
توبّهايى كه فقط به تخته برخورد مى كرد ا امتياز داشتند و به توبِهايى كه بيرون مىرفت، امتيازى تعلق نمى گرفت.

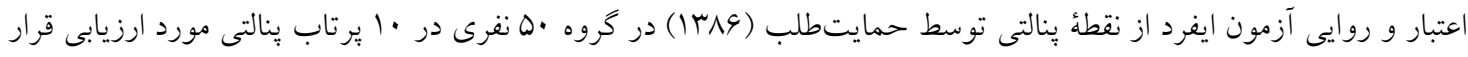

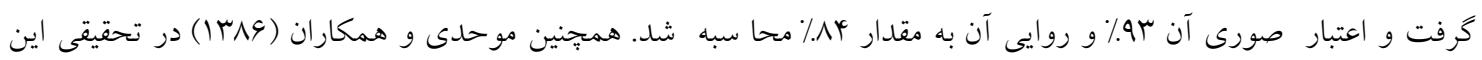

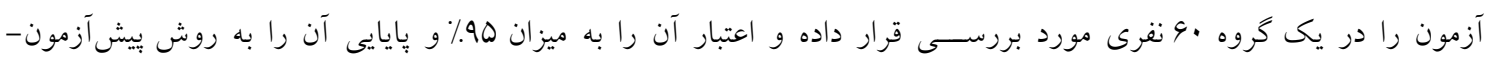

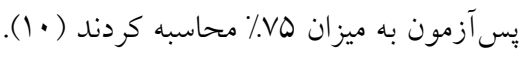

\section{روش كار}

اجراى اين تحقيق در شش مرحلهُ دستورالعمل آموزشى، بيش آزمون، تمرين، آزمون اكتساب، آزمون ياددارى و انتقال انجام شد. در مرحله د ستور العمل آموز شى تعداد •و نفر به صورت در د سترس با توبٍ بـسكتبال و نحوهُ يرتاب آزاد بـسكتبال آ شنا شدند.

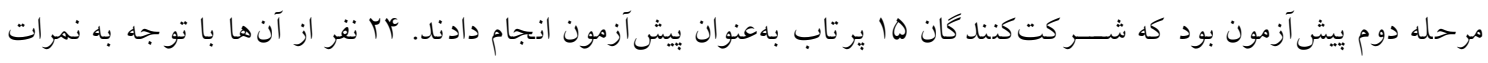

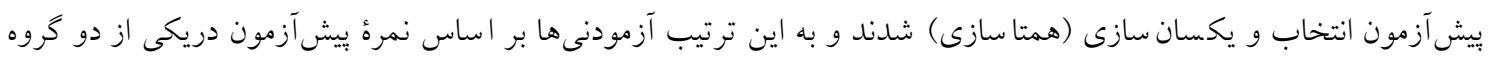
ז ا نفرى روش دونفره رقابتى و دونفره مشـاركتى قرار گرفتند. در مرحله تمرين ( يس از · ل دقيقه كرم كردن ) همة آزمودنىها تعداد ها كو شش به صورت r د سته كو شش ه تايى مهارت را در يك جل سه انجام دادند. گروهها به صورت دونفره به تمرين

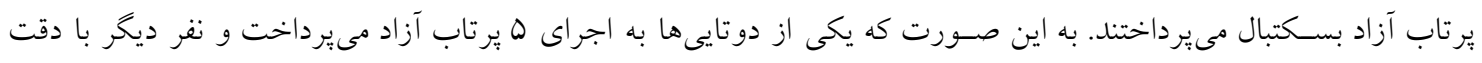

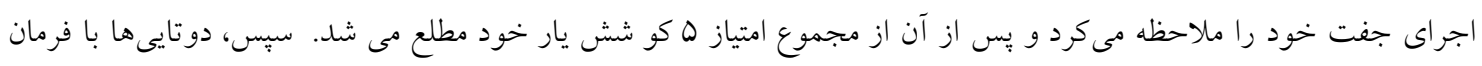
آزمونگر نقش خود را با هم عوض مى كردند. حال نفر دوم اقدام به اجراى ه كو شش مىكرد و يار او با دقت اجراى جفت خود ماد 


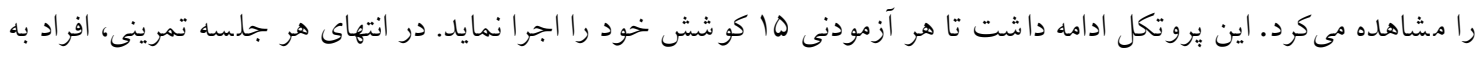

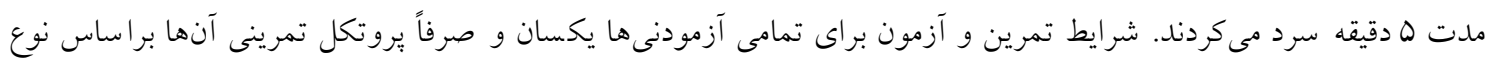

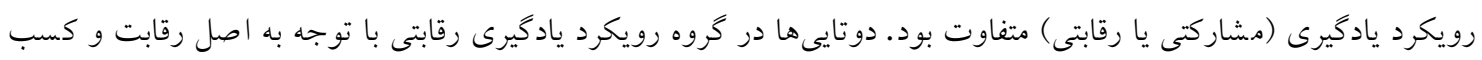

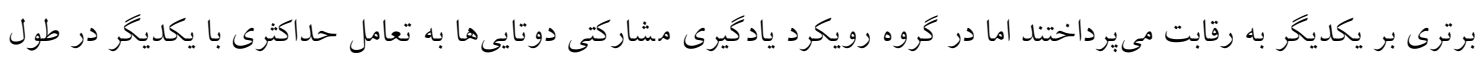
اجراى تحقيق تشويق مىشدند.

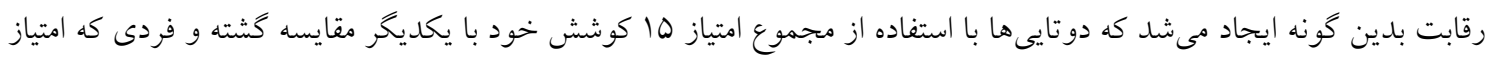

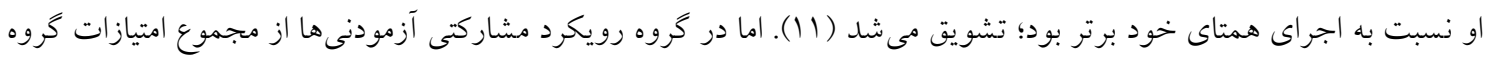

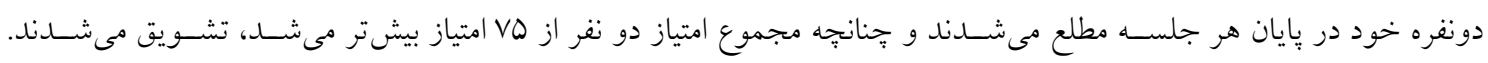

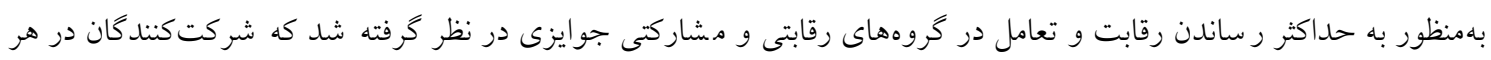

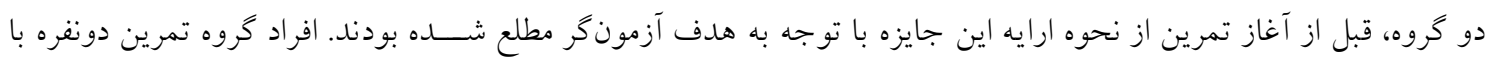

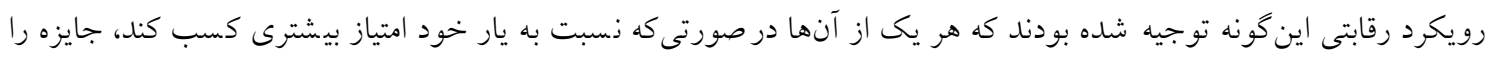

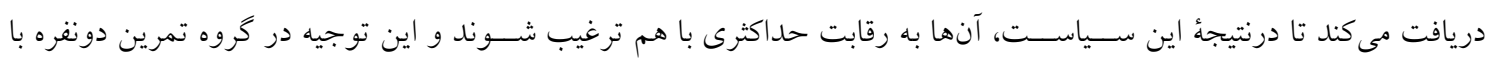

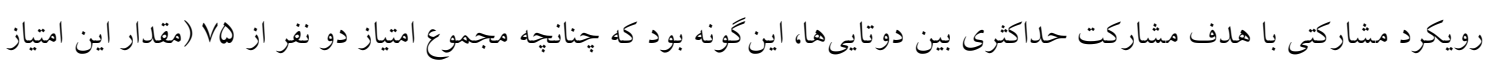

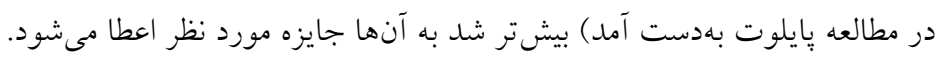

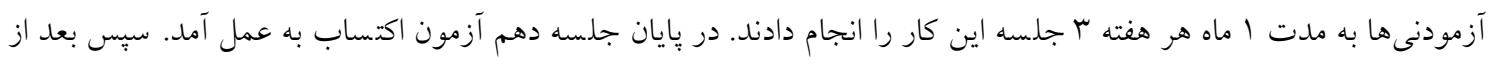

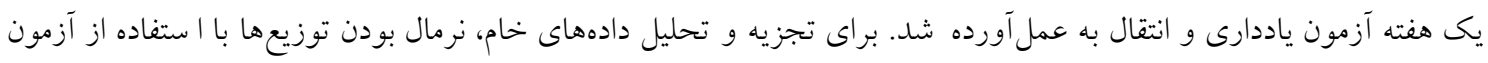

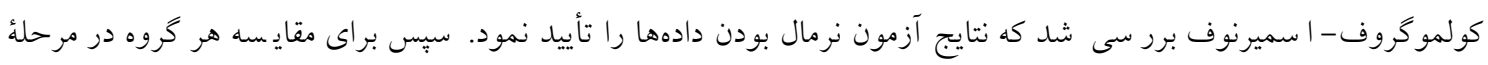

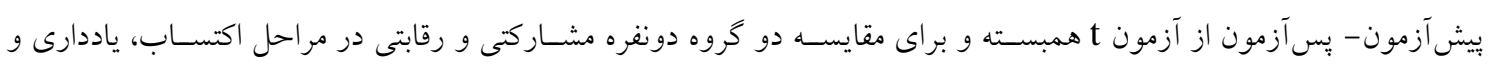

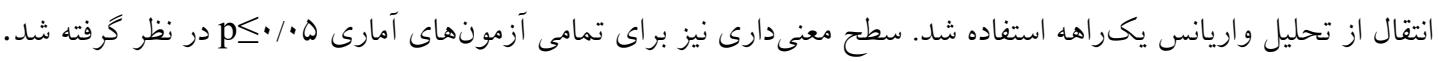

\section{يافتهها}

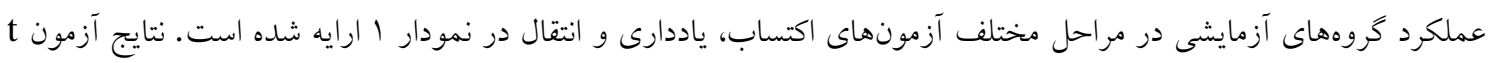

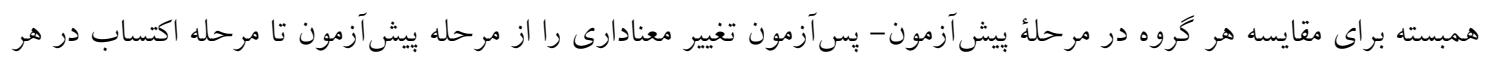

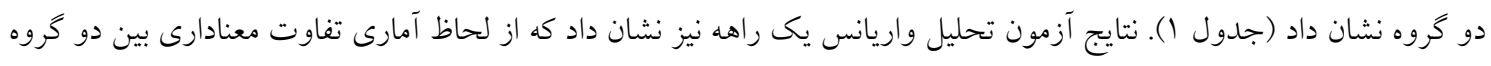
دونفره مشاركتى و رقابتى در مراحل اكتساب و ياددارى وجود ندارد اما در آزمون انتقال عملكرد افراد كروه تمرين دوتائي باديا

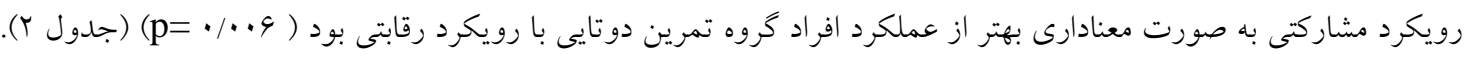

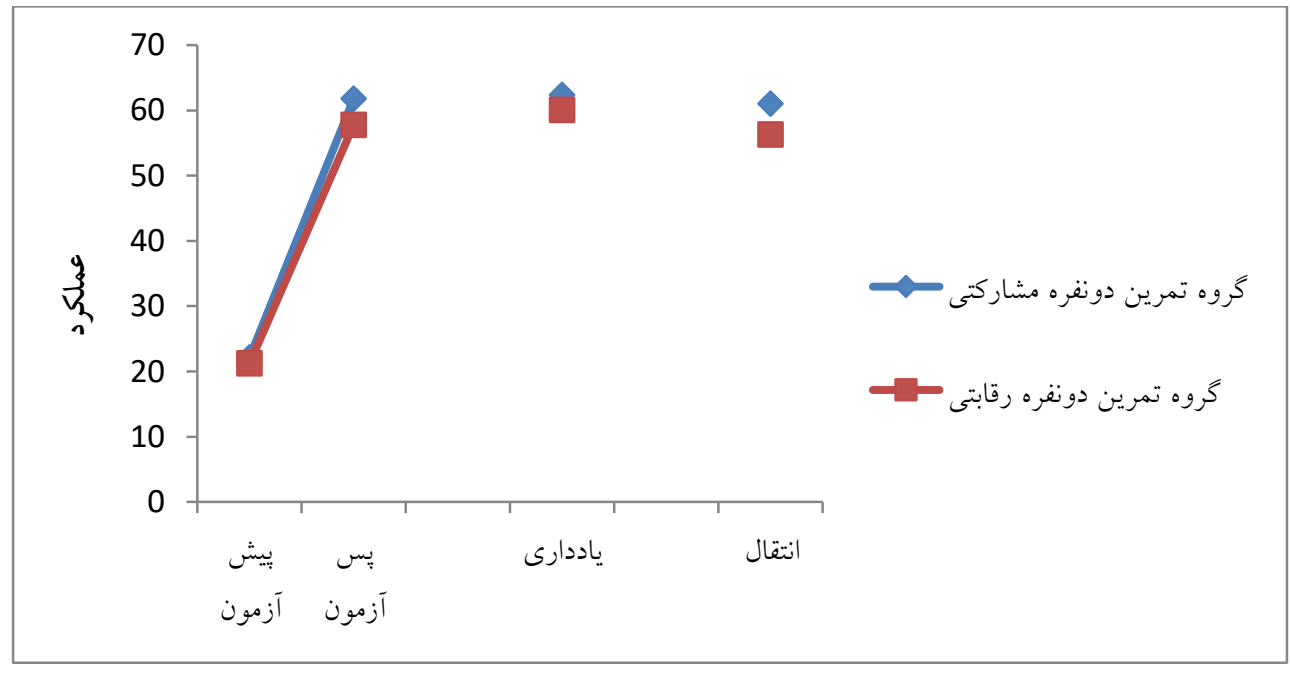

نمودار ا. عملكرد گروههاى آزمايشى در مراحل مختلف آزمونهاى اكتساب، ياددارى و انتقال 
جدول ا. نتايج آزمون t جفت شده به منظور مقايسه عملكرد افراد گروه تمرين دوتايى با رويكرد رقابتى و مشار كتى

\begin{tabular}{|c|c|c|c|c|}
\hline $\begin{array}{c}\text { سطح معنىدارى } \\
\text { (P) }\end{array}$ & $\begin{array}{c}\text { انحر اف استاندارد } \\
\text { S. D }\end{array}$ & ميانكين & منبع تغييرات & آماره \\
\hline \multirow{2}{*}{$=\cdot / \cdot r q$} & $9 / \pi 1$ & $T I / T Q$ & ي بيش آزمون & \multirow{2}{*}{ گروه تمرين دوتايى رقابتى } \\
\hline & $V / 09$ & OV/AT & آزمون اكتساب & \\
\hline \multirow{2}{*}{$* / \cdot 1 r$} & $r / 9 r$ & $T T / T V$ & ي يش آزمون & \multirow{2}{*}{ كروه تمرين دوتايى مشاركتى } \\
\hline & $9 / .4$ & $91 / \Lambda \mu$ & آزمون اكتساب & \\
\hline
\end{tabular}

$* \mathrm{P}<\cdot / \cdot 0$

جدول r. نتايج تحليل واريانس در مورد مقايسه عملكرد دو گروه در آزمون اكتساب، ياددارى و انتقال

\begin{tabular}{|c|c|c|c|c|c|c|}
\hline $\begin{array}{c}\text { معنى } 1 \text { مارى } \\
\text { (P) }\end{array}$ & $\mathrm{F}$ & $\begin{array}{c}\text { ميانكين مجذورات } \\
\text { (MS) }\end{array}$ & $\begin{array}{l}\text { درجه آزادى } \\
\text { (df) }\end{array}$ & $\begin{array}{l}\text { جمع مجذورات } \\
\text { (SS) }\end{array}$ & منبع تغييرات & آماره \\
\hline \multirow{2}{*}{$\cdot / 111$} & \multirow{2}{*}{$r / 94$} & س TM & Tr & V৭q/Tr & اثر متقابل كروهها & \multirow{2}{*}{ آزمون اكتساب } \\
\hline & & 99 & 1 & 99 & اثر بينكروهى & \\
\hline \multirow{2}{*}{$\cdot / 14 q$} & \multirow{2}{*}{.$/ \cdot r V$} & $1 V / 9$. & Tr & rar/Ar & اثر متقابل كروهها & \multirow{2}{*}{ آزمون ياددارى } \\
\hline & & $.199 \mathrm{~V}$ & 1 & $.199 \mathrm{~V}$ & اثر بينگروهى & \\
\hline \multirow{2}{*}{$\because / \cdots 4$} & \multirow{2}{*}{$9 / 419$} & $\mid Y / Q r$ & Tr & $M 19 / 0 \Lambda$ & اثر متقابل كروهها & \multirow{2}{*}{ آزمون انتقال } \\
\hline & & $I T \Delta / T^{\prime}$ & 1 & $I T \Delta / \mu V Q$ & اثر بين گروهى & \\
\hline
\end{tabular}

$* \mathrm{P}<\cdot / \cdot 0$

\section{بحث و نتيجه}

هدف از يزوهش حاضر، مقايسه روش تمرينى دونفره با رويكرد مشاركتى و رقابتى در اكتساب، ياددارى و انتقال مهارت يرتاب

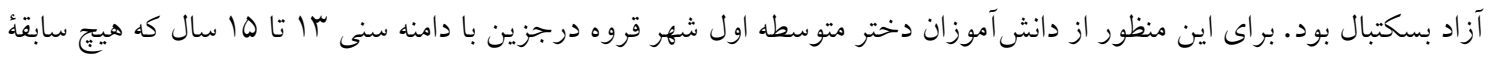

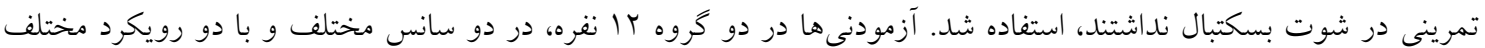

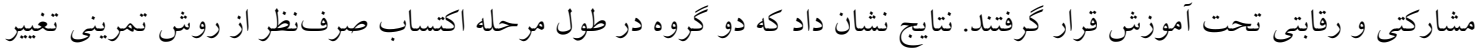

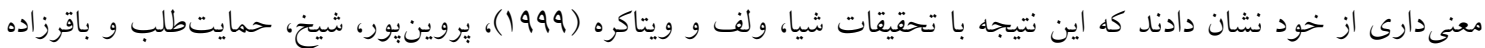

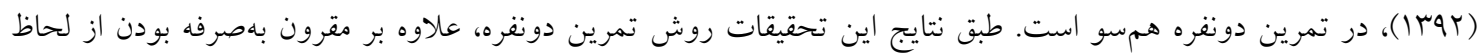

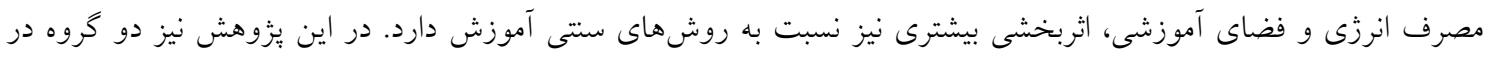

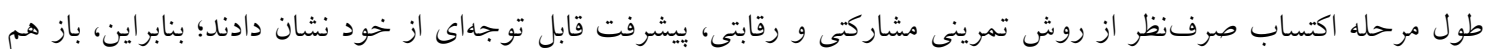
اثربخشى تمرين دونفره ديده شد. اما بين گروهها در آزمون اكتساب و ياددارى تفاوت معنادارى مشاهده نخرديد. از دلايل احتمالى اثربخشى روش تمرين دونفره با

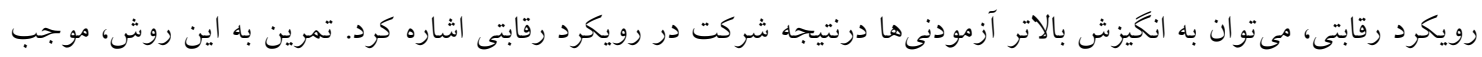

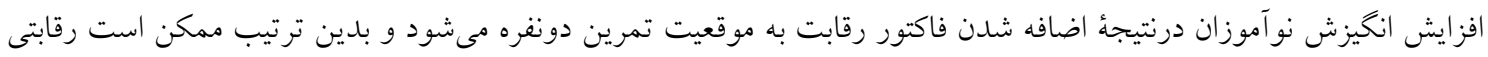

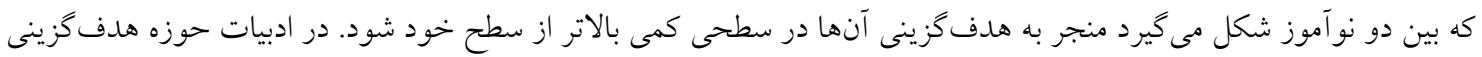


نشان داده شده است كه هدفهاى اختصاصى و كوتاهمدت (بهعنوان مثال جلو زدن از يار خود در روش تمرينى دونفره) منجر به عملكرد و ياد كيرى بيشترى از مهارتهاى حركتى مىشود (V). عامل احتمالى ديكرى كه در اثربخشى روش تمرين دونفره با رويكرد رقابتى مىتوان اظهار نمود جِنين است كه (احساس ديده شدن و مورد مقايسه قرار كرفتن) انخيزش را افزايش مىدهد. درواقع نهتنها مدل در حال يادكيرى منفعتهايى را براى كسى كه

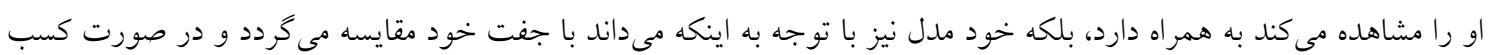

امتياز بيشتر نسبت به جفت خود تشويق مىشود، انخيزه بيشترى براى تلاش در ياد كيرى بيدا مىكند (Y) (1).

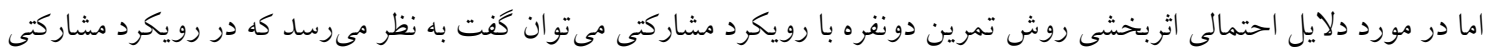
دركير كردن نو آموزان در فرآيند يادكيرى، خود موجب افزايش انخيزش آنها در ادامه فعاليت گرديده است. نوآموزان كروه تمرين

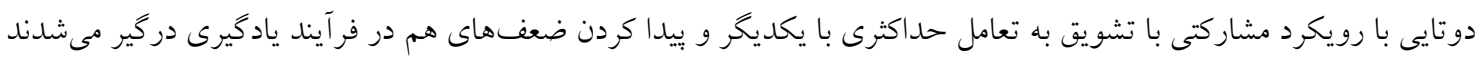
و اين امر عملكرد آنها را بالا مىبرد (V). نتايج بهدستآمده در مرحله اكتساب و ياددارى با تحقيق سليمانى شهروئى، فارسى، عبدلى (1||(1)، ميرانزاده، عربعامرى و

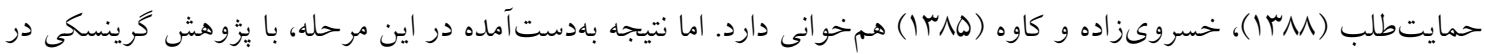
تضاد است. در اين راستا، كرينسكى (r 1994) با مقايسه روشهاى يادكيرى انفرادى، رقابتى و مشاركتى دريافت كه افراد شركت كننده در فعاليتهاى مشاركتى از نظر آمادكى جسمانى و بروز رفتارهاى اجتماعى در مقايسه با افراد شركت كننده در فعاليتهاى انفرادى

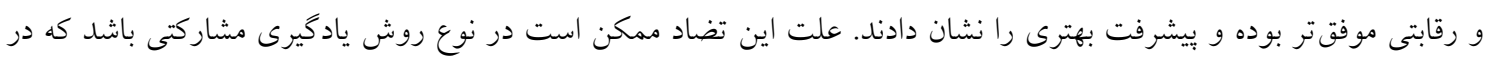
يزوهش حاضر با روش تمرين دونفره اعمال شده بود.

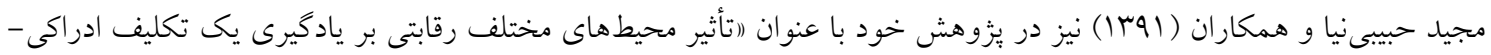
حركتى (دارت) در دانشآموزان كمتوان ذهنى" كزارش كردند كه هيج اختلاف معنىدارى بين دو گروه غيررقابتى و تركيبى وجود

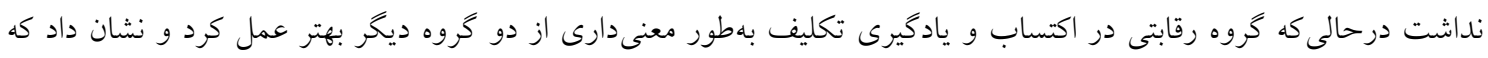

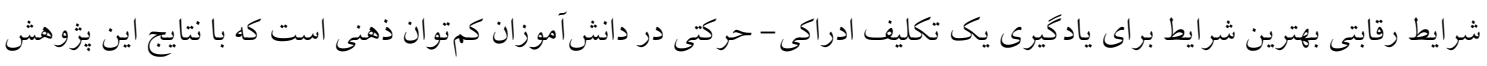
در تضاد است. ممكن است علت اين امر، نوع انتخاب آزمودنى ها كه يسران كمتوان ذهنى بودند و يا مقايسه محيطهاى مختلف بهري رقابتى در اين يزٔوهش و عدم مقايسه دو محيط يادگيرى رقابتى و مشاركتى باهم باشد.

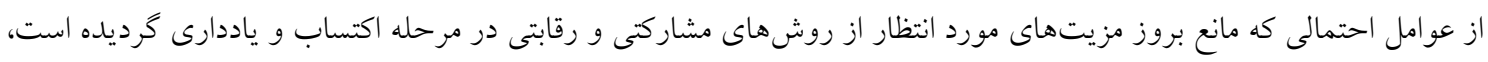
مىتوان اين احتمال را در نظر گرفت كه در تحقيق حاضر به دليل شرايط ايدهآل بهوجود آمده براى يادكيرى مهارت، از طريق

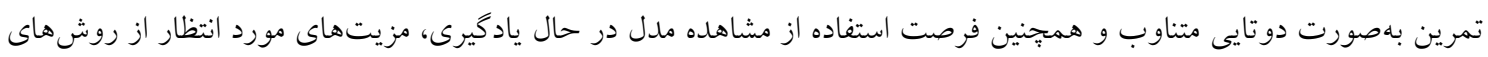
مشاركتى و رقابتى، به دليل مزيتهاى فراوانى كه از طريق يادكيرى مشاهدهاى در تمرين دونفره حاصلشده، قدرت بروز بيدا

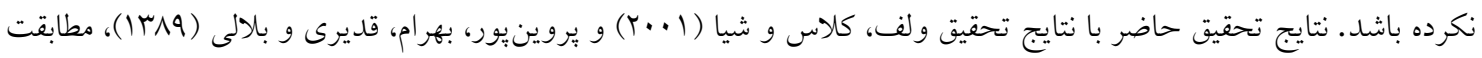

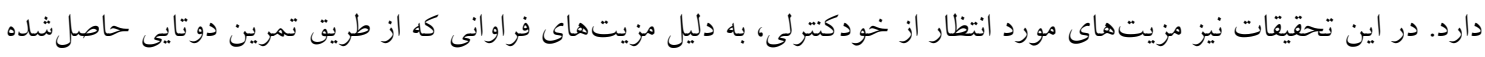
بود، قدرت بروز بيدا نكرد. نتايج مرحله انتقال نشاندهنده تفاوت معنى دار بين دو گروه تمرين دونفره با رويكرد مشاركتى و رقابتى به نفع روش تمرين دونفره با رويكرد مشاركتى است. درنتيجه مىتوان جنين اظهار نمود كه رويكرد مشاركتى نسبت به رويكرد رقابتى، اثربخشى بيشترى

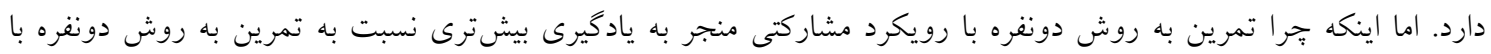
رويكرد رقابتى شد، بر اساس مبانى نظرى بهخوبى قابل توجيه مىباشد كه در ادامه به آن مى يردازيم.

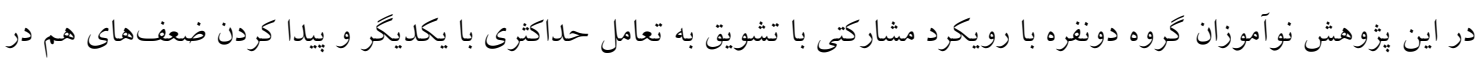

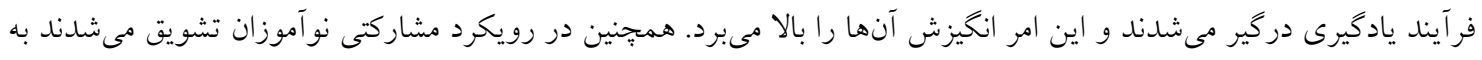
كمك هم براى رسيدن به هدفى مشترى تلاش كنند. از طرفى هم نوآموزان كروه مشاركتى در نقش مربى براى يكديخر بودند و

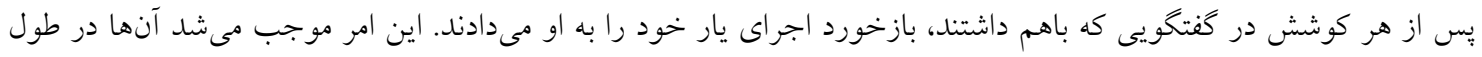
اين فرآيند مرجع تصحيحى را توسعه دهند كه در هنگام اجراى تكليف از سوى خودشان نيز مورداستفاده قرار كيرد. همجنين 
ممكن است دوتايىهاى مشاركتى راهبردهاى مختلف را در راستاى حل مسأله حركتى باهم به اشتراى مى گذاشتند كه اين امر

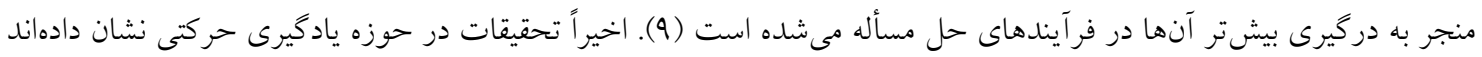
دركيرى بيشتر نوآموزان در فرآيندهاى حل مسأله با استفاده از روشهاى مختلف منجر به ياد كيرى بيشترى در تكليف موردنظر

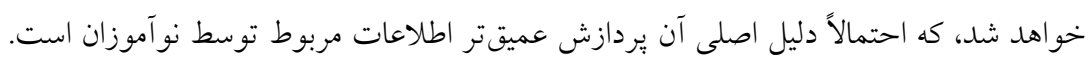

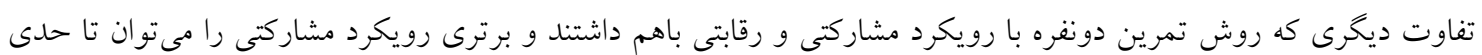
به آن نسبت داد، وجود تعاملات مثبت در ميان افراد گروه مشاركتى بود .يكى از عناصر اصلى يادكيرى مشاركتى برقرارى تعامل مثبت بين فراخيران است (سا). عنصر ديخرى كه از طريق يادگيرى مشاركتى تقويت مىشود مهارتهاى بين فردى و مهارتهاى مرتبط با تعامل در كروهاى كوجّى است كه در طول يادكيرى توسعه مىيابند و شامل شنيدن،تصميم گيرى مشترك،

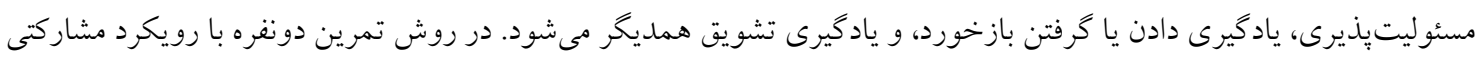

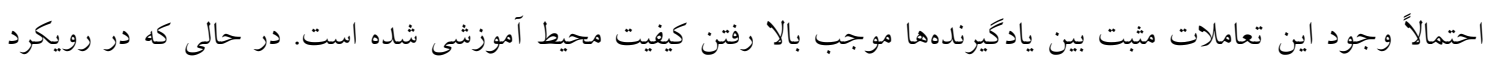
رقابتى روابط منفى را مىتوان بهعنوان يك عامل محدودكننده براى يادگيرى و اجرا در نظر كرفت. بوجيانو و همكاران (1994)

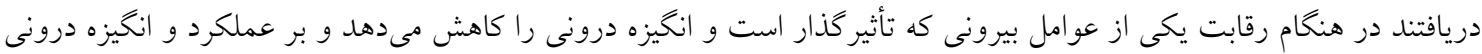

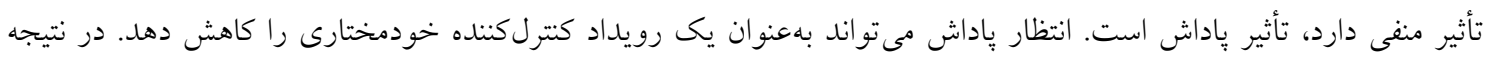
عملكرد را كاهش مى دهد. با توجه به اينكه افراد گروه تمرين دونفره با رويكرد رقابتى از طريق مجموع امتياز ها برتابشان با جفت خود مقايسه مى شدند و فردى كه امتياز او نسبت به اجراى همتايش برتر بود؛ تشويق مى شد، در آزمون انتقال كه لايههاى ينهان

يادكيرى را مىسنجل، عملكرد ضعيفترى نسبت به گروه دونفره با رويكرد مشاركتى در تكليف موردنظر از خود نشان دادند. با توجه به اينكه نتايج تحقيق حاضر نشان داد كه يادكيرى در روش تمرين دونفره با رويكرد مشاركتى بيشتر از روش تمرين دونفره با رويكرد رقابتى است، مىتوان با اين روش جهت افزايش كارايى و اثربخشى تمرين سود بيشترى برد. لذا به مربيان و معلمان

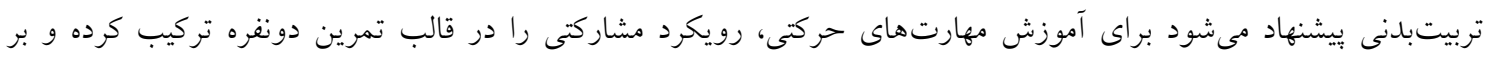
مشاركت حداكثرى دانش آموزان با يكديخر تأكيد نمايند.

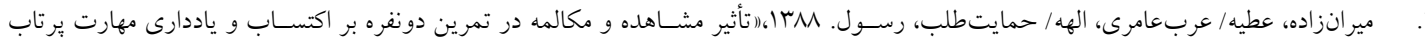

دارت)، ياياننامه كارشناسى ارشد، دانشعاه تهران.

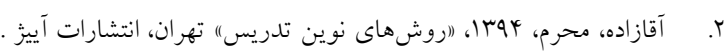

1. Grineski S, 1993, Children, cooperative learning, and physical education. Teaching Elementary Physical Education.

2. Deutsch M, 1949, An experimental study of the effects of cooperation and competition upon group process, Human relations.

3. Lee, T. D. , Wishart, L. R. , \& Cunningham, S. , \& Carnahan, H, 1997, Model timing information during random practice eliminates the contextual interference effect. Research Quarterly for Exercise and Sport, 68, 100-105.

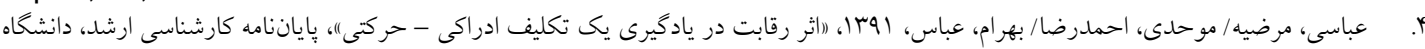

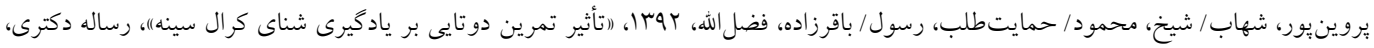

دانشخاه تهران.

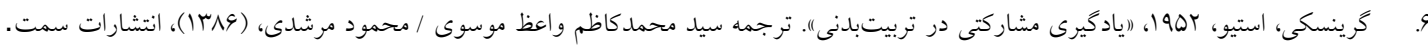

7. Shea $\mathrm{CH}$, Wulf $\mathrm{G}$, Whltacre C,1999, Enhancing training efficiency and effectiveness through the use of dyad training. Journal of Motor Behavior, 31(2):119-25

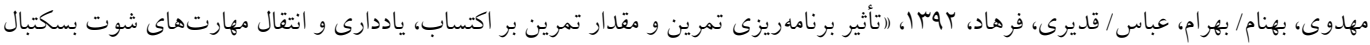

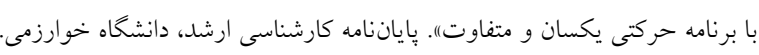

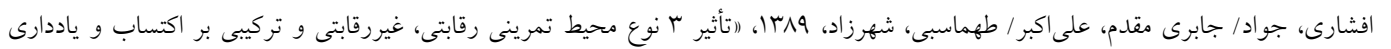

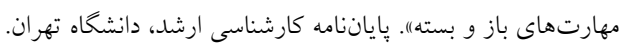

10. Wulf G \& \& Schmidt, R. A ,1997, Variability of practice and implicit motor learning. Journal of Experimental Psychology: Learning, Memory, and Cognition, 23, 987-b. 1006. 
11. Johnson DW, Johnson RT, Holubec EJ. 1998, Cooperation in the classroom: Interaction Book Company Edina.

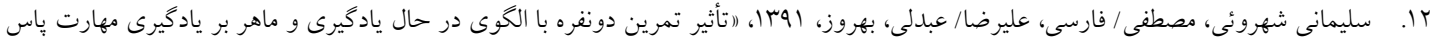

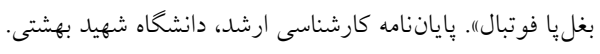

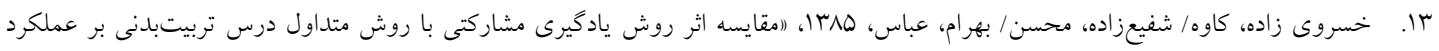

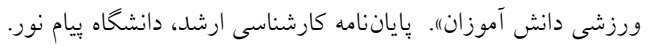

14. Wulf G, Clauss A, Shea CH, Whitacre CA. 2001, Benefits of self-control in dyad practice. Research quarterly for exercise and sport, 72(3):299-313.

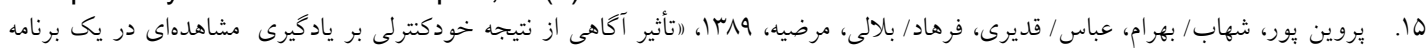

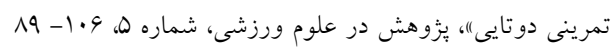

16. Adams, J. A. ,1986, Use of the model's knowledge of results to increase the observer's performance. Journal of Human Movemen Studies, 19, 89-98.

17. Barrett TMm, 2000, Effects of two cooperative learning strategies on academic learning time, student performance ,and social behavior of sixth-grade physical education students.

18. Magill, R. A. , \& Schoenfelder-Zohdi, B, 1996, A visual model and knowledge of performance as sources of information for learning a rhythmic gymnastics skill. International Journal of Sport Psychology, 27, 7-22

19. Putnam JW, 1993, Cooperative Learning and Strategies for Inclusion: Celebrating Diversity in the Classroom. Children, Youth \& Change: Sociocultural Perspectives: ERIC. 